\title{
胃癌治癒切除後の腫瘍マーカー測定の臨床的意義
}

\author{
石川県立中央病院外科 \\ 山田哲司森善裕北川 晋岩上榮 \\ 西浦和男広瀬宏一片田正一品川誠 \\ 高畠 一郎 中川 正昭

\section{CLINICAL EVALUATION OF TUMOR DETECTION OF TUMOR MARKER FOLLOWING CURATIVE OPERATION FOR GASTRIC CANCER}

\section{Tetsuji YAMADA, Yoshihiro MORI, Susumu KITAGAWA, Sakae IWAGAMI, Kazuo NISHIURA, Kouichi HIROSE, Syouichi KATADA, Makoto SINAGAWA, Ichirou TAKABATAKE and Masaaki NAKAGAWA} \\ Department of Surgery, Ishikawa Centural Prefectural Hospital
}

\begin{abstract}
術前腫瘍マーカー值が正常であった胃癌治瘜切除患者を対象として, 術後腫瘍マーカーの測定が再 発の早期発見に有用か否かの検討を加吝た。

腫場マーカーは carcinoembryonic antigen, $\alpha$-fetoprotein, carbohydrate antigen 19-9の 3 種を 測定し，対象患者440例の5ち88例飞術後再発を認めたが，腫場マーカー陰性再発例は52例 $(59.1 \%)$ を占めていた。

術後の combination assay による腫瘍マーカー陽性率はCEA が11.1\%と最も高かった。術後腫澔 マーカー低值群では $15.1 \%$ に, 高值群では $37.5 \%$ に再発が認められた腫瘍マーカー高值群に再発率が 高い（p<0.01）ことより，腫煌マーカーの測定は有用性のあるものと括もわれた。
\end{abstract}

霜引用語：胃癌治瘄切除, 尰瘍マーカー, carcinoembryonic antigen, $\alpha$-fetoprotein, carbohydrate antigen 19-9

\section{I. はじめに}

近年腫瘍免疫学の進歩に伴い $\alpha$-fetoprotein（以下 AFP と略す) ${ }^{1)}$, carcinoembryonic antigen(以下 CEA と略す)をははじめとする数々の腫瘍関連抗原が発見 され，腫瘍マーカーとして繁用されているのは周知の ことである。

胃癌においては現在臓器特異性の高い腫瘍マーカー の発見はなされていないわのの, CEA, carbohydrate antigen 19-9 (以下CA19-9 と略す) ${ }^{3)}$, tissue polypeptide antigen ${ }^{4}$ などの腫瘍マーカーの測定は有用であ るとの数多くの報告がある. しかし胃癌治癒手術後の

$<1989$ 年 5 月 8 日受理>別刷請求先：山田 哲司 干920-02 金沢市南新保町 153 石川県立中央病院 外科
定期的な腫瘍マーカーの測定が，再発の発見に有用か 否かの報告はきわめて少ない。

われわれは当科で治癒手術が行われ, 術後定期的に 腫瘍マーカーの測定が行われた胃癌症例につき，腫瘍 マーカーの測定が術後再発の早期発見に有用であるか 否かに検討を加え，若干の知見をえたので報告する。

\section{II. 対象および方法}

1977年 1 月から 1985 年12月までの 9 年間に当科で治 瘾手術が行われた胃癌症例のうち, 術前に測定された 腫瘍マーカー値がすべて正常でかつ術後す定期的に腫 瘍マーカーの測定がなされた男性288例，女性152例計 440例を対象とした.腫瘍マーカーの測定は原則として 術後 1 年以内は, 3 か月に 1 度, 術後 1 年以後は 6 か 月に 1 度以上行った. 対象患者 440 例のらち332例に絶 
表 1 対象症例

\begin{tabular}{|c|c|c|c|}
\hline 手術内容 & 男 & 女 & 平均年粭(歳) \\
\hline 絶対治㦄切除 & $222(19)$ & $110(11)$ & $66.4(65.7)$ \\
\hline 相対治癒切除 & $66(37)$ & $42(21)$ & $65.2(65.1)$ \\
\hline 竐 & $288(56)$ & $152(32)$ & $66.1(65.3)$ \\
\hline
\end{tabular}

対治癒手術が108例に相対治癒手術が施行され, 絶対治 癒手術の30例，相対治癒手術の58例計88例において 1988年 7 月の時点で再発が確認された（表 1).

測定された腫瘍マーカーは CEA, AFP, CA19-9であ り，CEAはダイナボット社 CEA 測定キット（ビーズ 固相法), AFPはダイナボット社 AFP 測定キット (ビーズ固相法)により当院で測定し，CA19-9は SRL 社に依頼し測定を行った。 CEA は30ng/ml, AFPは10 $\mathrm{ng} / \mathrm{ml}$, CA19-9は $40 \mathrm{U} / \mathrm{ml}$ を cut off 值とし,これ以上 の值をとった時を腫瘍マーカー陽性とした。

以上の対象群において腹水, Virchow 転移, doughras 窩転移, 腹痛などの理学的所見や, computed tomography (以下 CT と略す), urtrasonography (以 下USと略す) などの画像診断により臨床的に再発し たと判断される時点までに, 測定した 3 種の腫場マー カーすべてが cut off 值以下にあったものと, 1 度のみ cut off 值以上になったものを腫瘍マーカー正常群と し, 測定した腫瘍マーカーの 1 種でも 2 度以上 cut off 値よる高值をとったものを腫瘍マーカー高值群と区別 し，今回の検討を行った.

また腫瘍マーカーの sensitivity (感度), specificity (特異性), accuracy (正確度) は下記の式により算出 した.

sensitivity $=$ $\frac{\text { true positive }}{\text { true positive }+ \text { false negative }} \times 100(\%)$ specificity $=$

true negative true negative + false positive $\times 100(\%)$ accuracy $=$

true positive + true negative true positive + false negative $+\quad \times 100(\%)$ true negative + false positive

true positive : 再発 (十) で腫瘍マーカー陽性症例 false negative : 再発 $(+)$ で腫瘍マーカー陰性症例 true negative：再発 $($ 一) で腫瘍マーカ一陰性症例 false positive : 再発 (一) で腫煬マーカー陽性症例
表 2 各腫瘍マーカーの測定数および陽性数

\begin{tabular}{|c|c|c|c|c|}
\hline \multicolumn{2}{|c|}{ 手術内容 } & 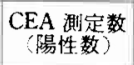 & $\underset{(\text { 陽性数 }}{\text { A }}$ & CA19-9測定数 \\
\hline \multirow{2}{*}{ 絶対治愁切除 } & 再発( - ) & $2253(171)$ & $2072(7)$ & $436(33)$ \\
\hline & 再発 $(+)$ & $192(37)$ & $174(0)$ & $33(4)$ \\
\hline \multirow{2}{*}{ 相対治意切除 } & 再発 一 & $465 \quad 51)$ & $449(4)$ & $85(9)$ \\
\hline & 再発 $(+)$ & 351 (104) & $316(1)$ & $42(5)$ \\
\hline \multicolumn{2}{|l|}{ 計 } & $3261(363)$ & $301112)$ & $596(51)$ \\
\hline
\end{tabular}

また胃癌に対する記述，分類はすべて胃癌取扱い規 約5゙にしたがった。

\section{III. 結 果}

1）腫場マーカー別陽性率

対象群における CEA は総計3,261回，AFP は総計 3,011回, CA19-9は総計596回測定されており，その陽 性率は CEA で11.1\%, AFP で0.4\%, CA19-9で8.6\% と CEA が最も高く、 AFPが最も低かった。再発群と 非再発群とに区別しその陽性率をみると CEA は非再 発群で $8.2 \%$, 再発群で $26.0 \%$ の陽性率であり, AFP は 非再発群 $0.4 \%$, 再発群で0.2\%の陽性率であり, CA199 は非再発群で $8.1 \%$, 再発群で $12.1 \%$ の陽性率であっ た. 以上 3 種の腫瘍マーカーは非再発群, 再発群のい ずれにおいても高値をとりらることが判明した。しか しこの 3 種の腫潅マーカーのらち再発群が, 非再発群 に比へ陽性率が有意に高かったのはCEAのみであり $(\mathrm{p}<0.05)$, 他の 2 種の腫瘍マーカーでは有意差を認 めなかった（表 2 ).

またそれぞれの腫痬マーカーの specificity, sensitivity, accuracy は表 3 のごとくであり, sensitivityは CEA が, specificity と accuracyはAFPが最も高 かった（表 3). しかし sensitivityの最も高かった CEA でもわずか $40.9 \%$ あり，術後に CEA が高值と なったとしても半数以上は再発が認められないこと や, 再発者数は CEA 高值群上り CEA 低值群に括いて 多いことを十分留意しておくことが必要と思われた。

2）手術内容と combination assayによる畽瘍マー カーとの関係

測定した 3 種の腫瘍マーカーの combination assay により, 腫瘍マーカーすべてが cut off 値以下にあった ものと，1度のみ cut off 值以上になったものを腫場 マーカー正常群とし, 測定した腫瘍マーカーの1種で も 2 度以上 cut off 值より高値をとったものを腫湟 マーカー高值群として, 以下の検討を加光た。

手術内容別に腫瘍マーカーの陽性率に検討を加えて 
表 3 各腫演マーカーと Combination assay

\begin{tabular}{|c|c|c|c|c|c|c|c|}
\hline \multirow{2}{*}{$\frac{\text { 腫 }}{\text { マー瘍 }}$} & \multicolumn{2}{|c|}{ 睡瘍マーカー正常 } & \multicolumn{2}{|c|}{ 腫瘍マーカー高値 } & \multirow{2}{*}{$\begin{array}{c}\text { Sensitivity } \\
(\%)\end{array}$} & \multirow{2}{*}{$\begin{array}{c}\text { Specificity } \\
(\%)\end{array}$} & \multirow{2}{*}{$\begin{array}{c}\text { Accuracy } \\
(\%)\end{array}$} \\
\hline & 患者数 & $\begin{array}{l}\text { 再発者数 } \\
\text { (再発率) }\end{array}$ & 患者数 & $\begin{array}{l}\text { 再登者数 } \\
\text { (再発率) }\end{array}$ & & & \\
\hline CEA & 344 & $52(15.1)$ & 96 & $36(37.5)$ & 40.9 & 82.9 & 74.5 \\
\hline $\mathrm{AFP}$ & 436 & $60(13.8)$ & 4 & $0(0)$ & 0 & 98.9 & 85.6 \\
\hline CA19-9 & 178 & $25(14.0)$ & 17 & $3(17.6)$ & 10.7 & 86.4 & 80.0 \\
\hline
\end{tabular}

表 4 Combination assay と手術内容

\begin{tabular}{|c|c|c|c|c|c|c|c|}
\hline \multirow{2}{*}{ 手術内容 } & \multicolumn{2}{|c|}{ 畽瘍マーカー正常 } & \multicolumn{2}{|c|}{ 腫瘍マーカー高値 } & \multirow{2}{*}{$\begin{array}{c}\text { Sensitivity } \\
(\%)\end{array}$} & \multirow{2}{*}{$\begin{array}{c}\text { Specificity } \\
(\%)\end{array}$} & \multirow{2}{*}{$\underset{(\%)}{\text { Accuracy }}$} \\
\hline & 患者数 & $\begin{array}{l}\text { 再登者数 } \\
\text { (再発率) }\end{array}$ & 患者数 & $\begin{array}{l}\text { 再発者数 } \\
\text { (再発率) }\end{array}$ & & & \\
\hline 絶対治癒切除 & 274 & $18(6.6)$ & 58 & $12(20.7)$ & 40.0 & 84.8 & 83.8 \\
\hline 相対治癐切除 & 70 & $34(48.6)$ & 38 & $24(63.2)$ & 41.4 & 72.0 & 55.6 \\
\hline 計 & 344 & $52(15.1)$ & 96 & $36(37.5)$ & 40.9 & 82.9 & 74.5 \\
\hline
\end{tabular}

表 5 Combination assay と stage

\begin{tabular}{|c|c|c|c|c|c|c|c|}
\hline \multirow{2}{*}{ stage } & \multicolumn{2}{|c|}{ 腫瘍マーカー正常 } & \multicolumn{2}{|c|}{ 尰瘍マーカー高値 } & \multirow{2}{*}{$\begin{array}{c}\text { Sensitivity } \\
(\%)\end{array}$} & \multirow{2}{*}{$\begin{array}{c}\text { Specificity } \\
(\%)\end{array}$} & \multirow{2}{*}{$\begin{array}{c}\text { Accuracy } \\
(\%)\end{array}$} \\
\hline & 患者数 & $\begin{array}{l}\text { 再発者数 } \\
\text { (再発率) }\end{array}$ & 患者数 & $\begin{array}{l}\text { 再登者数 } \\
\text { (再発率) }\end{array}$ & & & \\
\hline I & 181 & $2(1.1)$ & 31 & $3(9.7)$ & 60.0 & 86.5 & 86.8 \\
\hline II & 97 & $17(17.5)$ & 30 & $9(30.0)$ & 34.6 & 79.2 & 70.1 \\
\hline III & 61 & $30(49.2)$ & 30 & $19(63.3)$ & 38.8 & 73.8 & 54.9 \\
\hline IV & 5 & $3(60.0)$ & 5 & $5(100)$ & 62.5 & 100 & 70.0 \\
\hline
\end{tabular}

みると，腫瘍マーカーが正常でありながら再発を認め た症例は52例（15.1\%）であり，腫瘍マーカーが高值 で再発を認めた症例は 36 例 (37.5\%) であり腫瑒マー カ一高値例での再発率は高かった（ $\mathrm{p}<0.05 ）$ 。京た の sensitivityは40.9\%, specificity $282.9 \%$, accuracyは $74.5 \%$ であり sensitivity が低かった（表 4 ）。 絶対治撚手術では 30 例 $(9.0 \%)$ に再発が認められ腫瘍 マーカー高值群での再発率は腫瘍マーカー正常群より 有意に高かった。しかし腫場マーカーが高値群におい ても非再発例が再発例より多いことや, 再発例の半数 以上 $(60 \%)$ は腫瘍マーカー正常群において認められ たことは，絶対治㾋手術に打いて癌再発の早期発見の ための腫場マーカー測定は, 有用ではあるが十分とは い光ないとおもわれた。相対治癒手術においては腫瘍 マーカー正常群においても, 腫煌マ一カ一高値群飞お いても約半数は再発を認めており, 腫瘍マーカーの測 定は再発の早期発見には何ら役立っていないとおむわ れた。
3）進行度と combination assayによる畽煌マー カーとの関係

Stage と畽場マーカーとの関俰に検討を加えてみる と stage Iでは腫煌マーカー高値群での再発率は高い ( $\mathrm{p}<0.05)$ が, stage II, III，IV では有意差を認めな かった. Stage II, III での sensitivity, specificity, accurasyはいずれも低値となっていた（表 5 ). 腫瘍 マーカーが高值となり再発した群をみる限り stage が 進行するにつれ再発率が有意に上昇する $(\mathrm{p}<0.05)$ た め，腫場マーカーの測定は一見有用性が高い上うに思 われる。しかし腫場マーカーが正常でありながら再発 した群においても stage が進行するにつれ再発率は有 意に上昇していた。このため腫瘍マーカーの有用性の 検討には，同じ stage での再発率に検討を加えなけれ ばならないそそこで同一 stageでの再発率に検討を加 えてみると, 再発者数, 再発率ともきわめて低い, stage Iに拈いてのみ腫瘍マーカーの測定は意義が認められ た。しかし再発率が高く腫瘍マーカーの測定により癌 
表 6 Combination assay とリンパ節転移

\begin{tabular}{|c|c|c|c|c|c|c|c|}
\hline \multirow{2}{*}{$\begin{array}{l}\text { リンン゚ } \\
\text { 節転移 }\end{array}$} & \multicolumn{2}{|c|}{ 畽瘍マーカー正常 } & \multicolumn{2}{|c|}{ 腫瘍マーカー高値 } & \multirow{2}{*}{$\begin{array}{c}\text { Sensitivty } \\
(\%)\end{array}$} & \multirow{2}{*}{$\begin{array}{c}\text { Specificity } \\
(\%)\end{array}$} & \multirow{2}{*}{$\begin{array}{c}\text { Accuracy } \\
(\%)\end{array}$} \\
\hline & 患者数 & $\begin{array}{l}\text { 再発者数 } \\
\text { (再発率) }\end{array}$ & 患者数 & $\begin{array}{l}\text { 再発者数 } \\
\text { (䖤発率) }\end{array}$ & & & \\
\hline $\mathrm{n}_{0}$ & 210 & $12(5.7)$ & 38 & $7(18.4)$ & 36.9 & 86.5 & 82.7 \\
\hline $\mathrm{n}_{1}$ & 75 & $13(17.3)$ & 28 & $9(32.1)$ & 40.9 & 76.5 & 68.9 \\
\hline $\mathrm{n}_{2}$ & 56 & $26(46.4)$ & 28 & $19(67.8)$ & 42.2 & 76.9 & 58.3 \\
\hline $\begin{array}{l}\mathrm{n}_{3} \\
\mathrm{n}_{4}\end{array}$ & 3 & $1(33.3)$ & 2 & $1(50.0)$ & 50.0 & 66.7 & 60.0 \\
\hline
\end{tabular}

表 7 Combination assay と深達度

\begin{tabular}{|c|c|c|c|c|c|c|c|}
\hline \multirow[b]{2}{*}{ 深達度 } & \multicolumn{2}{|c|}{ 腫瘍マーーカー正常 } & \multicolumn{2}{|c|}{ 腫揘マーーカー高値 } & \multirow{2}{*}{$\begin{array}{c}\text { Sensitivity } \\
(\%)\end{array}$} & \multirow{2}{*}{$\begin{array}{c}\text { Specificity } \\
(\%)\end{array}$} & \multirow{2}{*}{$\begin{array}{c}\text { Accuracy } \\
(\%)\end{array}$} \\
\hline & 患者数 & $\begin{array}{l}\text { 再発者数 } \\
\text { (再発䇣) }\end{array}$ & 患者数 & $\begin{array}{l}\text { 再登者数 } \\
\text { (再発率) }\end{array}$ & & & \\
\hline $\mathrm{m}$ & 74 & $0(0)$ & 10 & $0(0)$ & 0 & 88.1 & 88.1 \\
\hline sm & 86 & $3(3.5)$ & 14 & $0(0)$ & 0 & 85.6 & 83.0 \\
\hline $\mathrm{pm}$ & 41 & $4(9.8)$ & 10 & $3(30.0)$ & 42.9 & 84.1 & 78.4 \\
\hline $\operatorname{ss} \alpha$ & 117 & $30(25.7)$ & 47 & $21(44.7)$ & 41.2 & 77.0 & 65.9 \\
\hline $\operatorname{ss} \beta$ & 20 & $13(65.0)$ & 11 & $8(72.7)$ & 38.1 & 70.0 & 48.4 \\
\hline ss $r$ 以上 & 3 & $1(33.3)$ & 3 & $3(100)$ & 75.0 & 100 & 83.3 \\
\hline
\end{tabular}

表 8 Combination assay と組織型

\begin{tabular}{|c|c|c|c|c|c|c|c|}
\hline \multirow[b]{2}{*}{ 組織型 } & \multicolumn{2}{|c|}{ 腫瘍マーカー正常 } & \multicolumn{2}{|c|}{ 畽瘍マーカー高値 } & \multirow{2}{*}{$\begin{array}{c}\text { Sensitivity } \\
(\%)\end{array}$} & \multirow{2}{*}{$\begin{array}{c}\text { Specificity } \\
(\%)\end{array}$} & \multirow{2}{*}{$\begin{array}{c}\text { Accuracy } \\
(\%)\end{array}$} \\
\hline & 患者数 & $\begin{array}{l}\text { 再発者数 } \\
\text { (再発率) }\end{array}$ & 患者数 & $\begin{array}{l}\text { 再発老数 } \\
\text { (再発率) }\end{array}$ & & & \\
\hline pap & 54 & $6(11.1)$ & 16 & $8(50.0)$ & 57.1 & 85.7 & 80.0 \\
\hline tub $_{1}$ & 52 & $2(3.8)$ & 16 & $6(37.5)$ & 75.0 & 83.3 & 82.4 \\
\hline $\operatorname{tub}_{2}$ & 49 & $6(12.2)$ & 26 & $9(34.6)$ & 60.0 & 71.7 & 69.3 \\
\hline por & 133 & $32(24.0)$ & 27 & $8(29.6)$ & 20.0 & 84.2 & 68.1 \\
\hline muc & 10 & $4(40.1)$ & 6 & $3(50.0)$ & 42.9 & 66.7 & 56.3 \\
\hline $\operatorname{siq}$ & 41 & $2(4.9)$ & 5 & $2(40.0)$ & 50.0 & 92.9 & 89.1 \\
\hline その他 & 2 & 0 & 0 & 0 & 0 & 100 & 100 \\
\hline
\end{tabular}

の再発を早期に発見したい stage II, III, IV 症例には 有意差はなく，測定の意義が認められなかった。

4）リンパ節転移と combination assayによる畽瘍 マーカーとの関係

組織学的リンパ節転移度と, 腫瘍マーカーとの関係 に検討を加えてみると， $\mathrm{n}_{0}$ 症例において specificity と accuracy が $\mathrm{n}_{1}, \mathrm{n}_{2}, \mathrm{n}_{3}$ 症例に比べ高檤をとるすのの, sensitivityはいずれも低値となっていた，畽瘍マー カーが正常か否かにかかわらず, $\mathrm{n}_{0}, \mathrm{n}_{1}, \mathrm{n}_{2}$ となるにつ れ再発率は高くなるものの $(\mathrm{p}<0.05)$, 同一リンパ節 転移程度で検討を加えると, 再発率の低い $n_{0}$ 症例にお いてのみ腫瘍マーカー高值群での再発率は有意に $(p<0.01)$ 高かった（表 6$)$. 以上より再発を早期に発
見したい $\mathrm{n}_{1}, \mathrm{n}_{2}, \mathrm{n}_{3}$ 症例には腫煌マーカーの測定は役 立たないとおもわれた。

5）組織学的潹達度と combination assayによる腫 場マーカーとの関係

組織学的深達度と腫場マーカーとの関係に検討を加 えてみると, pmでは腫場マーカー高値群での再発率 は有意に高い $(\mathrm{p}<0.05)$ むのの, 他の深達度では有意 差を認めなかった。 $\mathrm{s} \alpha, \mathrm{ss} \beta$ などの症例では sensitivityがきわめて低值をとっており（表 7)，再発の可能 性の高い症例には再発の早期発見のための腫場マー カーの測定は，意義のないものと思われた。

6) 組織型と combination assayによる腫瘍マ一 カーとの関係 
組織型と腫瘍マーカーとの関係に検討を加えてみる 之, 分化型 ( $\mathrm{pap}, \mathrm{tub}_{1}, \mathrm{tub}_{2}$ ) での腫瘍マーカー高値 群に拈ける再発率は有意に $(\mathrm{p}<0.05)$ 高いものの, 未 分化型 (por, sig)での再発率には有意差を認めなかっ た。 また por, sig などの未分化型での sensitivity が低 値をとっていた（表 8).

\section{IV. 考 察}

腫瘍マーカー測定の臨床的意義は癌種の存在診断, 進行度判定, 治痛効果判定, 予後あるいは再発の予知 などにあるとされる6゙。しかし現在広く使用されてい る腫瘍マーカーで癌を検出 (sensitivity), 非癌のすべ てを除外できる（specificity），信頼性の高い（accuracy）ものはない，とりわけ胃癌においては蔵器特異 性の高い腫瘍マーカーーの発見はなされておらず，数々 の腫瘍マーカーを組み合わせる combination assay 法を用いることによりこの目的を達成しょうとする数 多くの報告がみられる7)99. それらの結論はいずれも 進行胃癌の存在診断や進行度判定には有用であったと されているが, 消化管造影検査, 内視鏡検查, US, CT などの形態学的診断法の発達した胃癌に扔いては, 癌 種の存在診断や，進行度判定において腫場マーカーの 果た寸意義は小さいといわねばならない。そのため腫 瘍マーカー測定の意義は理学的所見や, 画像診断にて 再発が確認される以前に再発を予知できるか否かにか かっていると思われる。

胃癌術後の腫瘍マーカーの測定は再発の発見に有力 な手段となりらると報告されている論文 ${ }^{10) \text { 13) }}$ は, 術前 の腫瘍マーカー值が切除標本の組織学的進行度と相関 すること，ごく小数例に抢ける再発と腫助マーカー值 とに相関を認めたことを根拠にしている．しかしこの 結論をえるためには，多数の治癒切除症例における統 計学的検討がぜひとも必要なことと考光今回の検討を 行った.

術後の癌再発の有力なモニターとなりえると報告さ れている(1011)13) CEAは，われわれの検討でも陽性率は 最も高かった。しかしその sensitivityは低く, CEA が 低值でありながら再発する症例も多いことを考学れば 有効性のあるものの, 満足のいくものではなかった.

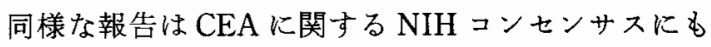
みられる ${ }^{14)}$ 。この報告では CEA 值は, CEA 陽性癌の モニターとして用いる時には有効であるが，膵癌，胃 癌，婦人科腫湯などに拈いて指標として用いるには信 頼性は高くはないと結論されている. Staabの slope aralysis $^{15)}$ をはじめとする術後の CEA 值の变動によ
り再発を的確につかむための方法む考案されてはいる が，CEA 值は個体差が大きく，性，年齢，梁煙習慣な どにも影響をうける ことなども考慮すれば更に精度 の高い胃癌腫瘍マーカーの開発が望まれる。

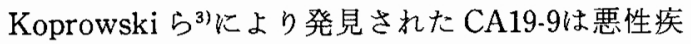
患では膵癌で79\%, 肝内・外胆道悪性腫瘍で $67 \%$, 大 腸癌で $39 \%$, 肝細胞癌で $49 \%{ }^{17}$, 良性疾患の慢性膵炎で は20\%の陽性率を示す ${ }^{18}$ 腫瘍マーカーとされている。 胃癌でる陽性率は比較的高く胃癌術前患者で $20 \%$, 再 発癌では $40 \%$ の陽性率を示し ${ }^{19)}, \mathrm{CEA}$ と同程度の有用 性を持つ々報告されている，われわれの成績での sensitivity はCEA より更に低くなって括り，CA19-9のみ での癌再発の発見は困難と思われた。しかしCA19-9 の specificity と accuracy はCEAより高いことより， リンパ郭清や膵切除に伴う慢性萃炎を否定さえでされ ば，本マーカーが高値となった時点での再発の可能性 はきわめて高いものと考学られた。

AFP は胃癌では脈管侵襲やリンパ節転移度の高い 進行胃癌において発現する腫瘍マーカーとされてい る20)が，われわれの成績では陽性率がきわめて低值で あることより胃癌術後の腫瘍マーカーとしての意味は まったくないものと思われた。

また 3 種の腫瘍マーカーの combination assay の 結果は, 手術内容, 病期, リンパ節転移, 組織学的深 達度のいずれで分類してみても， sensitivityは低いな がら specificity と accuracyはほぼ満足のいくわので あった。しかしこの值も, 病期では stage I, リンパ節 転移度では $\mathrm{n}_{0}$, 組織学的深達度では $\mathrm{m}, \mathrm{sm}, \mathrm{pm}$ など の，まず再発は考兄られない症例に打いて良く，再発 の早期発見に腫瘍マーカーの助けが必要な stage II,

III, IV 症例, $\mathrm{n}_{1}, \mathrm{n}_{2}, \mathrm{n}_{3}$ 症例, $\mathrm{ss} \alpha, \mathrm{ss} \beta$ 症例における 值はきわめて低かった。

尰煌マーカー高值例においてはいずれも高値となっ た時点で詳細な理学的所見と画像診断がなされていた が, 再発が発見されたのは全体の30\%の症例であった。 再発不明の少数例に括いては化学療法の変更や, 再度 の化学療法がなされた症例もあったが, 腫瘍マーカー 值の变動は, 追加化学療法の有無や化学療法の変更に は関係なく自然と正常值に復する症例も数多く認めら れた。

以上 CEA，AFP，CA19-9の 3 種の腫瘍マーカーの combination assayにより胃癌術後の再発の発見が可 能か否かに検討を加えたところでは, AFPを除いて不 十分ではあるが有用性はあるものと思われた。しかし 
尰瘍マーカーの値の推移に基ついて化学療法を開始し たり，変更したりするだけの信頼性に之しく，さらに 胃癌に特異的な腫瘍マーカーの開発がなたれるところ である。

\section{IV. 結 語}

胃癌治癒手術後の患者440例を対象として術後に経 時的に CEA, AFP, CA19-9の 3 種の腫瘍マーカーの测 定を行い, 再発の早期発見が可能か否かの検討を行い 以下の結論をえた。

1. CEA の陽性率は $11.1 \%$, AFPは0.4\%, CA19-9 は8.6\%と CEA の陽性率が最も高かった。

2. CEA 悱再発群で $8.2 \%$, 再発群で $26.0 \%$ の陽性 率で有意に再発群での陽性率が高かったが，他の 2 者 は再発群と非再発群に有意差を認めなかった。

3. Sensitivity $は$ CEA が, specifisity $と$ accuracy はCA19-9がすぐれておう，有用性を認めたが, AFP の 有用性はないと思われた。

4. 3 種の腫瘍マーカーによる combination assay では stage I 症例, 深達度 $\mathrm{pm}$ 症例, リンパ節転移度 $\mathrm{n}_{\mathbf{0}}$ 症例，組織型では分化型での有用性が認められた。

\section{文献}

1) Abelev GI, Pevova S, Khramkova NI et al : $\alpha$ 1-globulin by transplantable mouse hepatoma. Transplantation 1:174-180, 1963

2) Gold P, Freedman SO: Demonstration of tumor-specific antigen in human colonic carcinoma by immunological tolerance and absorption technique. J Exp Med 121 : 439-462, 1965

3) Koprowski H, Steplewski Z, Mitchell $\mathrm{K}$ et al : Colorectal antigens detected by hybrydoma antigens. Somatic Cell Genet 5 : 957-972, 1979

4) Bjorklund B: Antigenecity of malignant and normal human tissue by gell diffusion techniques. Int Arch Allergy 8: 179-192, 1956

5）胃癌研究会編：胃癌取扱い規約. 金原出版, 東京, 1985

6) 石井 勝編：腫瘍マーカーハンドブック.サイェ ンスフォーラム社編, 東京, $1985, \mathrm{p} 18-22$

7）小川健治, 成高義信, 湖山信篤ほか：胃癌, 大腸癌 に㧍ける腫瘍マーカーの臨床的有用性について 一外科的立場から TPA, CEA を中心に一, 癌の臨 $31: 638-647,1985$
8）浜副隆一, 古賀成昌, 前田迪郎注か：胃癌患者血清 中の tissue polypeptide antigen $と$ carbohydrate antigen 19-9 の臨床的評価. 日消外会誌 $20: 29$ $-33,1987$

9）米村 豊, 橋本哲夫, 沢 敏治ほか：胃癌患者にお ける血中 CEA, AFP, hCG 測定による Combina. tion Assay の臨床的意義. 日臨外医会誌 $48: 174$ $-179,1987$

10）尾崎行男, 池田芳明, 水沢清昭ほか：胃癌之 carcinoembryonic antigen一とくに治療効果, 予後と の関係について一. 日消外会誌 $17: 1403-1406$, 1984

11）島野高志, 奥田 博, 玉木康博ほか：癌の診断・治 療における腫㾮マーカーの意義, 胃癌, 大腸癌と CEA，CA19-9．治療 68:65-69，1986

12）浜野吉則, 駒田尚直, 今林伸康ほか：胃㿋患者にお ける carbohydrate antigen 19-9 の臨床的意義. 日 消外会誌 $18: 909-913,1986$

13) Tamada R, Hiramoto $Y$, Tsujitani $S$ et al : Serum CEA levels facilitate detection of recurence of cancer in patients after gastrectomy. Jpn J Surg 15:23-29, 1985

14) Carcinoembryonic antigen: Its roles as a marker in the management of cancer. Summary of an NIH consensus statement. Cancer Res $41: 2017-2018,1981$

15) Staab HJ, Anderer FA, Stumpf E et al: Slope analysis of the posyperative CEA time course and its possible applification as an aid in diag. nosis of disease progression in gastrointestinal cancer. Am J Surg 136 : 322-327, 1978

16）北村元士, 伊藤寿美子, 飯森系子任か：エンザイム イムノアッセイによる血清 CEA の正常値. 医のあ むみ $112: 519-521,1980$

17) Del Villano BC, Brennan $S$, Brock $P$ et al: Radioimmunometric assay for a monoclonal antibody defined tumor marker CA19-9. Clin Chem $29: 549-552,1983$

18）石井 勝編：腫煌マーカーハンドブック，サイエ ンスフォウラム社版, 東京, $1985, \mathrm{p} 226-237$

19）有吉 寛, 桑原正喜, 須山泰山ほか：糖鎖抗原 CA19-9, 新しい消化器関連抗原一膵癌腫瘍マー カーとしての可能性. 医のあゆみ $125: 918-920$, 1983

20）北岡久三： $\boldsymbol{\alpha}$-fetoprotein と転移細胞. 胃癌との関 係, 癌の臨 $79: 129-130,1981$ 